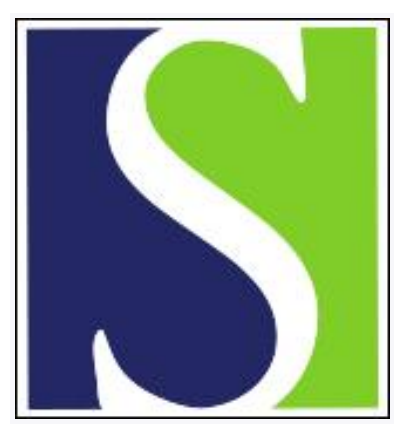

Scand J Work Environ Health 1997;23(4):308-310

https://doi.org/10.5271/sjweh.225

Issue date: Aug 1997

\title{
Sex-ratio variation in the Bille settlement
}

by Fertmann R, Schümann M, Karmaus W, Schmid-Höpfner S, Küppers-Chinnow $M$

Refers to the following text of the Journal: 1997;23(1):69

The following article refers to this text: 1998;24(1):74-73

This article in PubMed: www.ncbi.nlm.nih.gov/pubmed/9322823 


\section{Re: "Malignant melanoma among lithographers" by H Nielsen, L Henriksen, JH Olsen. Scand J Work Environ Health 1996;22:108-11.}

In a recent article in the Scandinavian Journal of Work, Environment \& Health (1), Nielsen et al reported a higher incidence of malignant melanoma among lithographers and suggested that hydroquinone may be implicated in the observed increased risk.

Overall, there was a nonsignificant decrease in the relative risk for cancer ( 24 versus 26.2 cases expected). In this population, 5 cases of malignant melanoma were observed versus 1.5 expected. The authors have suggested that exposure to hydroquinone, which is used as developer, may be associated with the higher incidence of melanoma. The suggested link between hydroquinone and melanoma is presumed because hydroquinone is known to reduce pigmentation when applied chronically to skin.

There are, however, epidemiologic data which suggest that hydroquinone exposure does not result in melanoma and experimental data that hydroquinone may be antineoplastic toward melanoma. Chavin et al (2) and Chavin \& Abramowitz (3) have shown that hydroquinone can, under certain circumstances, inhibit or destroy melanoma cells in vitro and in vivo. In a study in which mice were injected with NIH Harding Passey melanoma cells and given hydroquinone, the incidence of successful transplantation was reduced, and, although host survival was not elucidated, both the pharmacologic and the toxicologic effects of hydroquinone on melanoma cells may play significant roles (3). Of greater relevance to hydroquinone exposure in the workplace is the report of Pifer et al (4) on the mortality experience of 879 men and women working in a hydroquinone manufacturing plant. Overall cancer mortality in the cohort was significantly decreased (33 observed versus 57.9 expected, standardized mortality ratio $57,95 \%$ confidence interval $39-$ 80 ). In the combined category of "bone, connective tissue, skin and breast" 1 tumor versus 1.8 was observed, and this tumor was not a melanoma.

Overall, we do not believe that the available data would support a link between hydroquinone exposure and an increased incidence of malignant melanoma in lithographers.

\section{References}

1. Nielsen $H$, Henriksen L, Olsen JH. Malignant melanoma among lithographers. Scand J Work Environ Health 1996;22:108-11.

2. Chavin W, Jelonek JR EJ, Reed AH, Binder LR. Survival of mice receiving melanoma transplants is promoted by hydroquinone. Science 1980;208:408-10.

3. Chavin W, Abramowitz J. Molecular alteration in murine melanoma induces by melanocytolytic agents. Pigment Cell $1979 ; 5: 213-23$.

4. Pifer JW, Hearne FT, Swanson FA, O'Donoghue JL. Mortality study of employees engaged in the manufacture and use of hydroquinone. Int Arch Occupat Environment Health 1995;67: 267-80.

Betsy D Carlton, PhD, Hasmukh Shah, PhD

Chemical Manufacturers Association Hydroquinone Panel 1300 Wilson Boulevard

Arlington, VA 22209 USA

\section{Sex-ratio variation in the Bille settlement}

Integrating recent data on the sex ratio of births (measured as the proportion of boys among all newborns) James (1) related fathers' exposure to dioxin to signifi- cantly more daughters among their offspring. Mocarelli et al (2) described the sex ratio observed in Seveso for 74 total births during a period of 7 years with an excess of females (26 boys; 48 girls; sex ratio $=0.351$ ). DimichWard (3) reported on significantly more daughters for workers in the sawmill industry and presumably exposed to chlorophenate wood preservatives (19 675 infants born from 1952-1985; sex ratio 0.486). Both ratios differ 
significantly from the expected sex ratio of 0.514 .

The Bille settlement east of Hamburg, Germany, was built in the 1950 s on a contaminated sludge layer with high concentrations of arsenic (maximum $211 \mathrm{mg}$ arsenic/kg soil), heavy metals (eg, cadmium maximum $18.6 \mathrm{mg} / \mathrm{kg}$ soil), and dioxins and furans (PCDD/F maximum $3855 \mathrm{ng} / \mathrm{kg}$ international toxicity equivalents according to NATO/CCMS). From 1991 to 1996 an environmental health program was conducted to investigate the body load and possible health effects of the 700 inhabitants $(4,5)$. In 1991, when most of the families abandoned the settlement, 84 children up to 16 years of age were registered; their sex and age group are listed in table 1 . There is a significant excess of male children in the younger subgroup.

For the Bille settlement these registration data were validated by the results of the environmental health program. Questionnaires concerning the gynecological biography of women from the Bille settlement and the statistical analysis controlling for different windows of exposure disclosed similar results. Mothers exposed at the time of conception in the Bille settlement gave birth to 104 boys and 69 girls (sex ratio 0.60). In addition, it was observed that Bille couples displayed a prolonged time to pregnancy (6). The association between more male births and reduced fertility in the Bille sample contrasts with the recently published observation of Weijin \& Olsen (7), who reported on an unselected Danish sample of mothers and found that more female births were related to reduced fertility.

For the Bille inhabitants information about the body load of the contaminants before or during the time of conception is not available. Human monitoring in 1991 could not disclose significantly higher concentrations for the study group as a whole. Yet persons who had consumed home grown animal products had higher concentrations of dioxins and furans in their blood (range 21214 I-TEQ ppt PCDD/F blood concentration, $\mathrm{N}=16$ ) compared with persons with normal food consumption (range 12-84 I-TEQ ppt blood concentration, $\mathrm{N}=16$ ) (7). Exposure estimates for the whole study group indicated surplus exposure, especially for those who had grown up in the Bille settlement and stayed there parenting the next generation (8).

Our observation is contrary to the recently published data of Mocarelli et al (2) and Dimich-Ward et al (3). Any comparison of course has to consider weighty differences in exposure, exposure assessment, sample size, and structure. For example, Seveso as a well-known case of an accident deliberation, especially the congener TCCD in high concentrations contaminated men and women alike. On the other hand, the Canadian study relates to wood preservatives encompassing a range of toxic substances contaminating male sawmill workers. At least the Bille settlement represents a sustained expo-
Table 1. Number of male and female children registered in the Bille settlement in 1991 for 2 age groups and the sex ratio and test statistics (asymptotic test for binomial distribution with Yates-correction). The expected sex ratio 0.514 was used as the reference value for the statistical testing.

\begin{tabular}{lccccl}
\hline $\begin{array}{l}\text { Age group } \\
\text { (years) }\end{array}$ & Male & Female & N & $\begin{array}{r}\text { Sex } \\
\text { ratio }\end{array}$ & Test statistics \\
\hline $1-8$ & 34 & 6 & 40 & 0.85 & $\begin{array}{l}u=4.09, P \leq 0.001 \\
\mathrm{u}=0.27, \mathrm{NS}\end{array}$ \\
\hline $9-16$ & 24 & 20 & 44 & 0.55 & $\mathrm{u}$ \\
\hline Total & 58 & 26 & 84 & 0.69 & $\mathrm{u}=3.13, \mathrm{P} \leq 0.001$ \\
\hline
\end{tabular}

sure to arsenic, heavy metals and PCDD/F for several generations of residents in contact with the soil and by consumption of home-grown food stuff, affecting males and females, children and adults, as well as the status of preconception and the pregnant status.

On the basis of these different observations, we want to direct attention to 3 aspects.

First, because of the lack of reliable exposure data, we have yet no evidence about the possible means of interference of xenobiotics during reproductive maturation or during fertilization, implantation, and early development. Could possibly xenobiotics disturb male rather than female fertility? Could further analyses reveal time-dependent effects of noxious agents like $\mathrm{PCDD} / \mathrm{F}$ during especially susceptible periods of development? Should we rather investigate a distorted ratio of viable $\mathrm{x} / \mathrm{y}$ sperm or male-female zygotes during early impregnation in the determination of sex ratio deviations at birth? How should we control for fetal loss, assuming a different sex ratio in fetuses?

Second, corresponding to the data of Mocarelli et al, the Bille data pose the problem of small numbers. Empirical data present the variability of the sex ratio dependent on the denominator's size. For comparison our ongoing analysis includes a model of the distribution of sex ratio values with simulated data especially considering small birth cohorts (in preparation).

Third, a follow-up study is planned to examine reproductive impairment of the Bille inhabitants after exposure has been dissolved.

\section{References}

1. James WH. The sex ratio of offspring sired by men exposed to wood preservatives contaminated by dioxin. Scand J Work Environ Health 1997;23:69.

2. Mocarelli P, Brambilla P, Gerthoux PM, Patterson DG Jr, Needham LL. Change in sex ratio with exposure to dioxin. Lancet 1996;348:409.

3. Dimich-Ward H, Hertzman C, Teschke K, Hershler R, Marion SA, Ostry A, et al. Reproductive effects of paternal exposure to chlorophenate wood preservatives in the sawmill industry. Scand J Work Environ Health 1996;22:267-73.

4. Schümann M. Bille housing area. In: The Toxicology Forum 
Inc, editor. Current views on the impact of dioxins and furans on human health and the environment. Berlin/Washington: The Toxicology Forum Inc, 1993:264-70. Epidemiology and Clinical Investigations.

5. Behörde für Arbeit, Gesundheit und Soziales Hamburg, editor. Epidemiologisches Untersuchungsprogramm Bille-Siedlung. Frankfurt/M: Peter Lang Verlag 1997.

6. Küppers-Chinnow M, Karmaus W, Dreyer A. Schwangerschaft und Fertilität. In: Behörde für Arbeit, Gesundheit und Soziales Hamburg, editor. Epidemiologisches Untersuchungsprogramm Bille-Siedlung. Frankfurt/M: Peter Lang Verlag 1997:373443.

7. Weijin Z, Olsen J. Offspring sex ratio as an indicator of reproductive hazards. Occup Environ Med 1996;53:503—4.
8. Dulon M, Karmaus W, Steiner M, Pleß T, Höldke B. Exposition, Expositionsabschätzung und interne Belastung. In: Behörde für Arbeit, Gesundheit und Soziales Hamburg, editor. Epidemiologisches Untersuchungsprogramm Bille-Siedlung. Frankfurt/M: Peter Lang Verlag 1997:69—158.

Regina Fertmann, PhD, ${ }^{1}$ Michael Schümann, PhD, ${ }^{1}$ Wilfried Karmaus, MD, ${ }^{2}$ Sieglinde Schmid-Höpfner, ${ }^{1}$ Marion Küppers-Chinnow, $M D^{2}$

1 State Department of Labor Health and Social Affairs Hamburg Division Health and Environment Tesdorpfstraße 8 D-20148 Hamburg Germany

2 NORDIG Institute for Health Research Hamburg Germany 